\title{
Cultural landscape of the Gorica Hills in the nineteenth century: Franciscean land cadastre reports as the source for clarification of the classification of cultivable land types
}

https://doi.org/10.1515/geo-2020-0191

received December 30, 2019; accepted September 05, 2020

\begin{abstract}
The Gorica Hills (Slovene Goriška brda and also Brda) represent a part of the hilly cultural landscapes in the northern Mediterranean. Because of the historical development of the states, the Gorica Hills are situated on the Slovenian western border. The Gorica Hills have been a synonym for a cultivated landscape since the Middle Ages. New studies have changed the pre-existing belief that the cultivation method and crop types have not changed through the centuries, except for the introduction of corn and potatoes. However, detailed descriptions of the cultivation methods and the types of predominant crops in the cadastre show that during the nineteenth century, and especially in the period after World War I, the cultivation method of the vine and the types of crops, in fact, changed significantly. At this point, the nineteenth century can be seen as the period of the final introduction of corn and potatoes. Thus, the cultural landscape of the Gorica Hills is the result of the responses to inside and outside economic and cultural pulses. The paper will point out the advantages of the land cadastre reports that were used in the reconstruction of the cultural landscape. It will also present the questions that have remained unanswered and are left open for further research.
\end{abstract}

Keywords: Gorica Hills, Franciscean land cadastre reports, mixed culture, cultivable methods, brajda, terraces, fields with vines

\section{Introduction}

The European Landscape Convention states that a landscape is an area, as perceived by people, whose character is the result of the action and interaction of natural and/

\footnotetext{
* Corresponding author: Tanja Gomiršek, History department, Goriški muzej, Nova Gorica, Slovenia, e-mail: tanja.gomirsek@goriskimuzej.si
}

or human factors [1]. Cultural landscape, on the contrary, is the "result of human action into natural space in which nature is the medium and man represents culture." Each generation or historical period leaves its own imprint on cultural landscape. In fact, cultural landscape is a dynamic formation in perpetual change [2]. The area indicates the realities of the society of the time, whose population arranges it in their own way. Therefore, cultural landscape mirrors the period in which it is being created. It enables us to study the challenges faced by past societies, as well as their capacity for solving them within their knowledge. According to British historian and geographer Hoskins, cultural landscape is the most important historical document, as long as one is able to read it [2]. Defining the concept of cultural landscape, of how to study and classify it, is the work of many disciplines, from history, geography, architecture to agronomy. UNESCO recognises that "cultural landscapes embrace a diversity of interactions between people and the 'natural' environment. Cultural landscapes often reflect specific techniques of sustainable land-use, considering the characteristics and limits of the natural environment they are established in, and a specific spiritual relation to nature" [3]. Each and every landscape is an interlacing of past and present. That is why the approach of today's generation towards the past and our ancestors' achievements is also very important. Many researchers, both historians [4-14] and geographers [15-22], have contributed important studies related to this topic. The aim of this paper is not to reduce the importance of all the research results, but to prove that historical evidence can help us upgrade our knowledge on cultural landscapes. Using the archival sources for gathering information about the past landscapes is familiar not only to geographers and historians but also to historical geographers and landscape ecologists. The surveys were largely based on the use of historical cadastral maps and accompanying classification of the land plots. With the development of new technologies, the researchers have the possibility to use a geographic information system (also written as historical GIS or HGIS) that may display, store and analyse the data of past geographies and track changes in time. 
According to the confirmed percentage of inaccuracies in the old cadastral maps, current research goes beyond their use in historical reconstruction of the use of the cultural landscape. This also affects currently valid reconstructions of cultural landscapes that were made with their use [23]. The present study aims to draw attention to another question which the researcher must pay attention to when studying the Franciscean map. The paper will show the differences between classifying the individual land plot and the cultivation methods in the past and today. We cannot find this type of data using only maps but using the archival sources describing the cultivation methods and cultivated plants. The accompanying material of the cadastral maps from the first half of the nineteenth century, the so-called Franciscean Cadastre reports that are detailed and comprehensive descriptions of the land plots, is analysed. The survey will show that in the first half of the nineteenth century compared to the twentieth century, there were significant differences between cultivation methods and crops on equally classified land plots. This is a question that any research that compares the cultural landscape in the past and nowadays must answer.

\section{The region and the terraces of the Gorica Hills}

The Gorica Hills region is predominantly situated in Slovenia with a smaller proportion lying in Italy (Figure 1). As early as the late Middle Ages, a border crossed its western part which divided it up to World War I (WWI) [24]. During the New Ages the Gorica Hills were a border area between the Habsburg Monarchy and the Venetian Republic [25]. The Gorica Hills region belongs to the cultural landscapes of the Mediterranean hills and consists of a soft flysch [26]. It is characterised by an intricate mosaic of forests, agricultural landscape patterns and built-up areas. The area's dramatic terrain makes it even more diverse and different from the agricultural landscapes of the plains and the vast cultivated areas that result from intensive farming [25]. The Gorica Hills have been synonymous for a cultivated hilly landscape since the Middle Ages [26,27]. In fact, the region has been characterised by a mixed cultivation of vineyards, fruit trees and sowing land plots situated on terraces as well as fields. Because of a partially mechanised cultivation, nowadays the cultivated areas situated on hills and in plains are characterised by monoculture, i.e. vines, fruit trees, olive trees and less frequently crops. The mixed cultivational

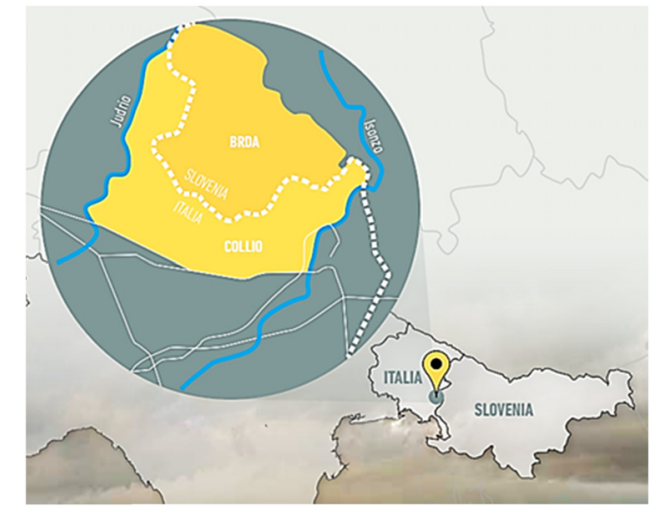

Figure 1: Gorica hills position between the states of Slovenia and Italy (The map is made by the Italian scientific and technical committee (coordinator arch. Elisa Trani) for the WHL UNESCO “Brda Collio Cuei Paesaggio culturale Transfrontaliero terrazzato" project and approved by the Slovenian scientific and technical committee).

ratio that was typical before WWI is rare. The only plants that coexist alongside the vine, albeit with a certain distance, are olive trees and fruit trees, which are grown on the edges of plots, longer banks or in plantations.

The cultural terraces of the Gorica Hills have been documented since the Roman times. In fact, archaeological excavations on the Mejnik hill in Gonjače have proven the existence of cultural terraces as early as in the third to fourth century $\mathrm{AD}$ [28]. In the year 238, the Roman writer Herodianus described the hills of our province as planted in unequal distances and with vines that swirl across the hills creating a joyful spectacle that makes the entire area seem to be decorated with crowns made of leaves $[29,30]$. The production of wine and olive oil during the Roman period is further proved by the archaeological site of Borg near Neblo, which dates back to the first century AD. The site was once a brickmaking facility that produced not only tegulae but also amphoras that were sold locally for storing wine and perhaps also oil [31]. Winegrowing, vines and cellars are mentioned in numerous medieval documents from the fourteenth and fifteenth centuries. One such document from the year 1321 states that Saint Martin's monastery in Cividale had two vineyards on the hill of St Florian and one cellar nearby San Floriano del Collio - Števerjan [32]. Within the jurisdiction exchange between the Colloredo nobility and the della Torre family, an interesting map of the central Gorica Hills was created in 1604 [33]. The map's author frequently wrote the term ronchi on the hills surrounding Dobrovo, Biljana and Vedrijan, which historically documents the fact that in the seventeenth century the hilly areas of the Gorica Hills were predominantly covered by terraces. Given the terrain's surface (steep inclinations) and its 


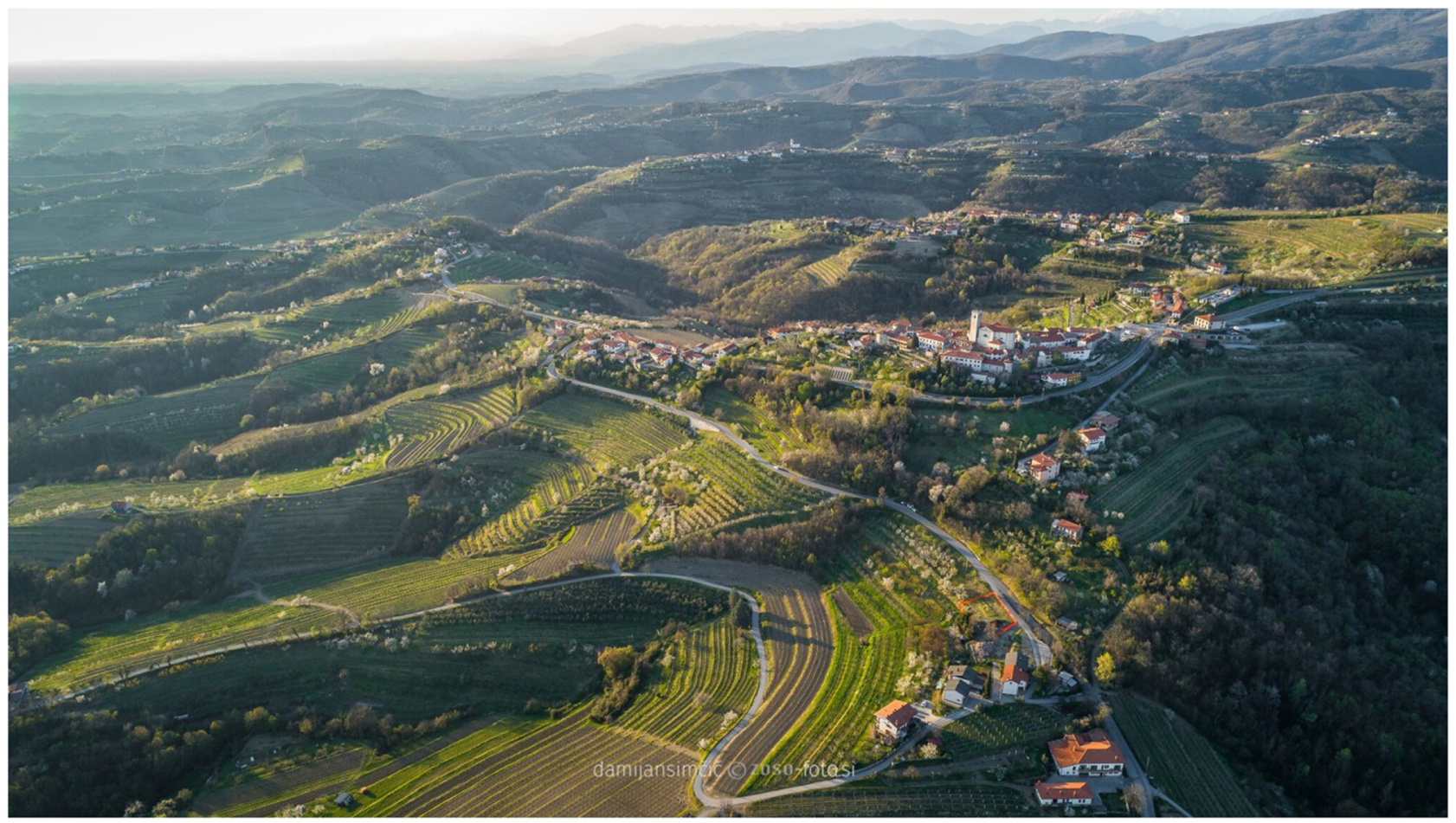

Figure 2: The landscape of Gorica hills today (photo collection ZTKMŠ, author Damijan Simčič).

morphological composition (flysch base), any other form of cultivated landscape on this hilly landscape is not possible. The term ronco is also used to describe the plots on the hills in the Theresian Cadastre that was created in 1751 and 1752. The feudal due that is always mentioned on these plots [34], the wine tent is already confirmed by the Gorizia manorial extent (urbarium) from the early $16^{\text {th }}$ century [27]. A tangible source for the Gorica Hills' terrace-building history is the reports featured in the Franciscean Cadastre made in 1824. These offer a detailed description of the cultivation methods of different plots, which are defined in the Cadastre's surveys. The plan for the cadastral municipality of San Floriano del Collio - Števerjan [35] includes in its annex sketches that illustrate single terrace-building phases, whereas the process itself is thoroughly described at the beginning of the cadastre plan. The description illustrates the importance of the correct building process and the knowledge that was passed down from one generation to another among the population of the Gorica Hills. The material demonstrates that the sources that were written in the Italian language of the time and had a strong influence of Friulan used the expression ronco for the local expression brajda [36]. Therefore, the term ronco that is used in these sources describes a mixed cultivation of vines, fruit trees and crops on terraces. These have preserved as an element of cultural landscape in the Gorica Hills throughout the twentieth century to this day (Figure 2). Their specific nature has induced the field team of the Slovenian Ethnographic Museum (SEM) to carry out a thorough documentation after World War II (WWII). The material, known under the label SEM, by Orel's team 1953, field $10 \mathrm{Brda}$, is composed of field notes, sketches and photographic material. As a result, the terraces of the Gorica Hills can be attributed a tradition of over 1,500 years that has been preserved despite the devastation caused by wars in the sixteenth, seventieth and twentieth centuries.

\section{Methods}

As demonstrated, the cultural terraces of the Gorica Hills have a centuries-old tradition. Nevertheless, the question arises whether the same plants grew on the plots and whether they were cultivated in the same way as it was known and considered to be traditional in the period following WWII. In fact, the studies that touched upon the cultivation methods and crop types featured a firm belief on what the cultural or, to be more precise, the agrarian landscape in the Gorica Hills was like in the past. On the hills (Figure 4), a system of terraces with one or two lines of vines positioned next to poles, the plain surface was sometimes used for crops, whereas 


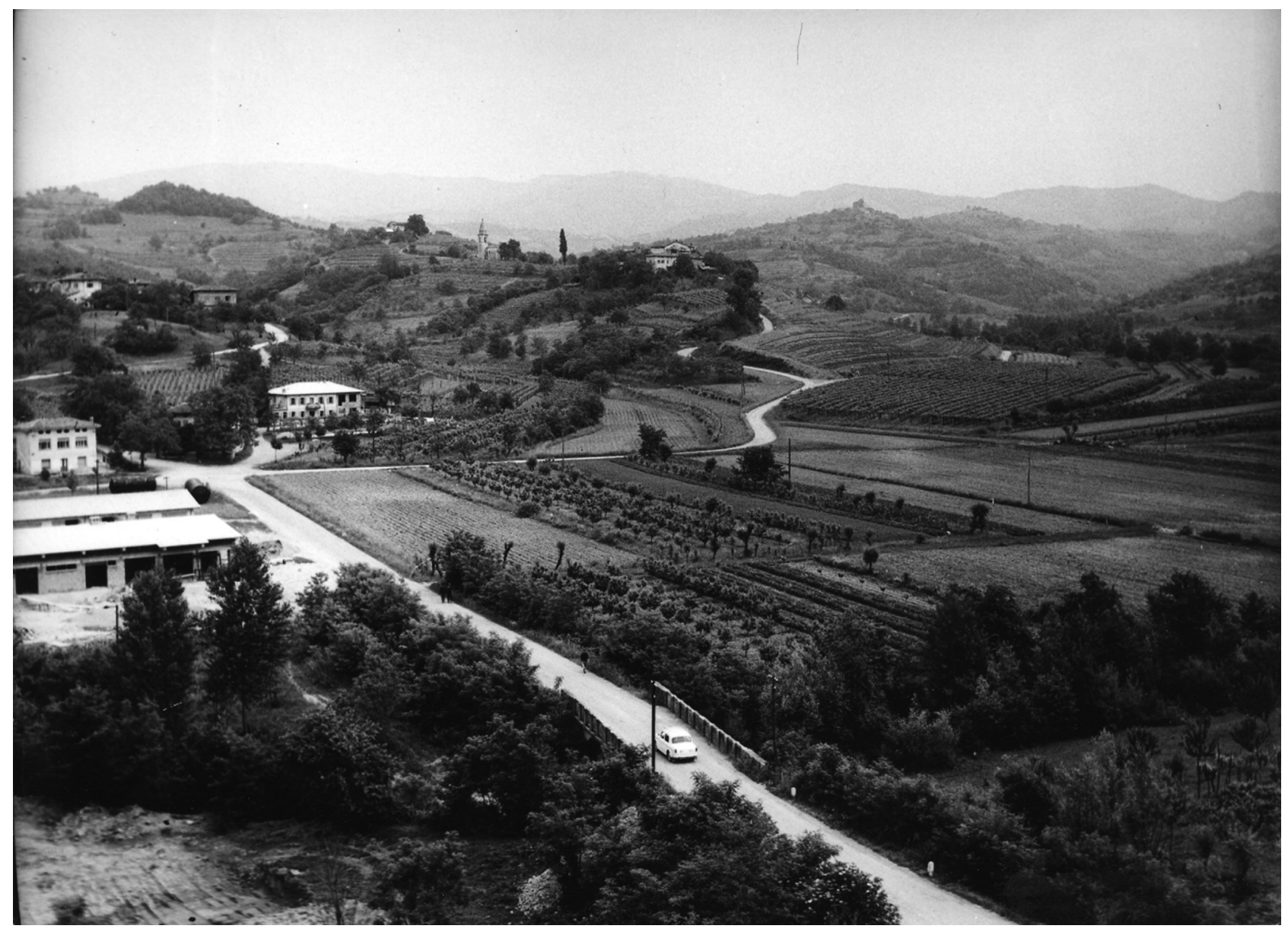

Figure 3: Fields featuring detached plots with vines, crops or fruit trees in 1956 (photo collection Goriški muzej).

the banks were used for fruit trees [37]. The fields were planted with vines, crops or fruit trees (Figure 3). Until more detailed studies have not been undertaken, there was a wide-spread belief that throughout the centuries the cultivation method and crops have not changed, apart from the introduction of corn and potatoes.

Based on the descriptions that are featured in the Franciscean Cadastre reports, the similarities and differences with regard to the above-mentioned belief will be illustrated. The survey is mostly relied on the description of the cultivation method of the two prevailing cultivated land plot types, the so-called brajda on the hills and the fields on the plains. Thus, the Cadastre reports represent an important source for studying cultural landscapes from the past. However, in spite of their very detailed descriptions, the cadastre reports do not provide an explanation to certain questions that remain unanswered.

The studies of the Franciscean cadastre reports pose to the researcher several problems: the linguistic one, as they are written in the Italian language, which was in use in Gorizia and its surroundings in the first half of the nineteenth century. Translating, the researcher encounters the obstacles, as many of the terms originate from the local dialect. The translation requires the use of special dictionaries and studies that have already researched the issue $[5,6,8,73,78]$. For example, zagotto means wooden two-wheeled cart with a wicker basket. The local and national historical length and weight measures units were also used, which need to be transformed into those we use today. Often used form "as customary" poses to the researcher the need for the use of additional archival material and search data. The researcher must ask to what extent the locals who collaborated with the officials in the census tried to show higher costs and lower incomes to reduce their tax payment. The latter is certainly evident in the references to the fruit trees. The problem of inaccurate information had already been noticed by the state officials, as they wrote: "Sembra, all'udire tutti I proprietarj nel Distretto di Quisca, insignificante il prodotto delle frutta, fra le quali si numera le Ceriegie, i Peri, gl'Armelini, i Susini, Fichi e le Castagne, e questa loro protesta deriva dal non percepire loro che al piú qualche 


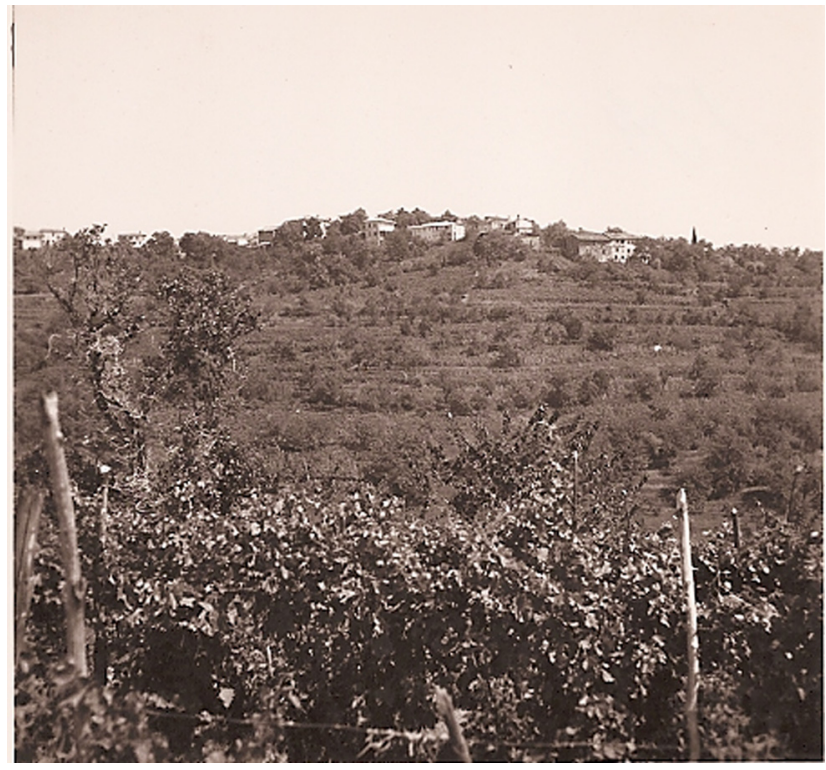

Figure 4: Brajdas featuring mixed cultivation in 1958 (photo collection Goriški muzej).

cesto dei medesimi, ma é cosa certa, che se I coloni non ricavarebbero dai terreni tenuti in affitto un discretto profitto dalle frutta, essi giá mai potrebbero vivere colloro famiglie. When you listen to all the masters from the Kojsko district, the yield of fruit, including cherries, pears, apricots, plums, peaches, figs and chestnuts, it seems insignificant. They claim that they do not grow more than a basket of fruit, but it is certain that the tenants, without a certain fruit product, would not be able to survive."

\subsection{Archival sources}

The land cadastre is a land recording of the terrains, which is carried out by the state to determine a uniform tax assessment on land [38]; in other words, "an official register of the actual state of land" [25]. In the eighteenth and nineteenth centuries, several cadastres were made for the Slovene territory. The first cadastre to be created for the Gorica Hills, then under the County of Gorizia, was the Theresian Cadastre, named after the Empress Maria Theresa. It was made in the years 1751-54, whereas for the rest of the Slovene territory, already in 1747 [39]. The land plot survey, known as the Jospephine Cadastre, was ordered by Emperor Joseph II in 1785. Both cadastres have their own advantages but also their own flaws. Consequently, they were soon followed by the creation of a new cadastre. The first real land plot survey that was carried out on our territory was in the year 1800 during the French occupation. It included some cadastral municipalities surrounding Gorizia [39]. Later, based on a patent from 1817, the Franciscean Land Cadastre followed, which represented a uniform and stable cadastre [40]. The cadastre survey for the majority of the Slovene territory was completed in 1828 . The material of the Franciscean Cadastre, which includes the majority of the Slovene territory, is preserved in good condition and kept by the Archives of the Republic of Slovenia. The material that includes the Gorica Hills, on the contrary, is kept by the State Archives of Gorizia and Trieste. Till the sixteenth century, the most part of the Gorica Hills was incorporated in the county of Goriška, which was a part of the Habsburg hereditary lands. Gorica (Italian Gorizia) and for some time also Trst (Italian Trieste) were the administrative centres of the county. In the post-WWII period, Gorizia and Trieste were incorporated in the republic of Italy. That is why the most of the archive sources for the Gorizia Hills nowadays are not in Slovenia but in Italy.

The Franciscean Cadastre as the source was already used by many researchers in landscape studies in regions and states of the former Habsburg Monarchy (Czech Republic, Slovakia, Slovenia, Austria, Croatia and so on), most often by geographers and historians. The studies of historians, except the study of Golec [41], are constructed on the examples of small rounded parts of Slovenian territory [5,42-49]. Among the geographical studies, the study of the social and geographical development of the Trieste hinterland by Andreas Moritsch [50] should be mentioned. An extensive volume researching Bukovina was published in 2015 [51]. In the last years, a large number of studies and articles related to the data provided by the cadastre material were published, among others, also a special issue of the Geographical Journal (published in 2018) [40,52-62]. The studies of historians explained the political and economic situation in which the cadastre was created. If Verbič in her study [42] is satisfied only with the publication of the content of the source, the authors of the further studies pointed out the disadvantages of the source, especially the inaccuracies of the data provided by farmers to reduce the tax [43-49]. Studies on changes in land use, based on cadastral maps of the Franciscean cadastre, show a similar methodological course. The first geographical studies in Slovenia have used the data from the maps of the Franciscean cadastre and compared them with today's situation. Cadastral maps represent cultivable land plots according to the nineteenth century classification. Based on the maps, the previously mentioned comparative studies were created. The written part was 
first used at the national level by Czech geographers, who created a land-use database covering the period from the mid-nineteenth century to 2010 and used it to study the factors influencing land-use changes [61,62]. The new studies made by geographers [57-59] show that the quality of data of different components of the Franciscean cadastre for the same cadastral municipality differs because of different methods of work and different interests of data authors. The statements of the Franciscean land cadastre reports are not entirely accurate and comprehensive; however, the data from the agricultural questionnaire are generally even more biasedly pessimistic. Simultaneous comparison of the data from various components of the Franciscean cadastre material is required as well as its critical use. The latter means that we are necessarily aware of the ways and motives for the emergence of this resource.

The results regarding the change of the share of cultivable land are accurate. For the results researching the share of the types of cultivable land, at least as far as Goriška brda is concerned, a revision would be necessary. The question what an individual cultivable land plot meant in the nineteenth century can be in a great extent answered by the Franciscean land cadastre reports that list the cultivation methods, types of crops, costs and incomes on the individual land plot. The definitions of land plots can be found in work registers, whereas their detailed descriptions are featured in the cadastre reports. These were made separately for each cadastral municipality and they integrate significantly the image of the landscape [40], which shall be portrayed in greater detail. It is not possible to compare the previously mentioned studies with this one. In this study, the share of different crops on the cultivable land plots is investigated, whereas the already mentioned studies compare the changes in the share of cultivable and non-cultivable land plots. The present survey tries to solve the question about exact meaning of cultivable land plots in the Gorica Hills region. This is merely one of the starting points for further multidisciplinary studies of the cultural landscape history.

\section{Results}

Descriptions of cultivated land plots, created in 1953 by a team of ethnologists, tell us that the prevailing surfaces on the hills were the so-called brajdas, apart from small and intensively cultivated gardens [63]. The brajda (D. Zuljan, The agricultural lexis of the village of Medana [the Goriška Brda region, Slovenia] from the point of view of the Slavic-Romance language contact, submitted for publication) can be defined as a terraced land plot with a mixed cultivation of vines, fruit trees and crops [64]. Mixed cultivation (cultura mista), which means areas where several crops are grown together, was in the past typical for several Mediterranean areas [55]. For the terraced areas in Slovene Istria, namely Krkavče and Merče, this mainly includes various crops mixed with grapevines or olive groves [55]. The Gorica Hills' mixed culture on brajda surface, on the contrary, mostly included vines and to lesser extent fruit trees and crops. Gardens were small and intensively cultivated surfaces dedicated to growing vegetables for home consumption. Fields were stretching on smaller and plain surfaces located at the foot of the hills. The fields were planted with vines, crops or fruit trees. By looking into the Theresian Cadastre and also the Josephine and Franciscean Cadastres, one is surprised by the definition of the cultivated fields as fields with vines - arativo avidato - that prevail in plain areas. In the cadastral municipalities of SE Gorica Hills, which are nowadays in Italy and comprehend the municipalities of San Mauro - Štmaver, Piuma - Pevma, Oslavia - Oslavje and San Floriano del Collio - Števerjan, all fields are labelled as fields with vines. In SW Gorica Hills, to be more precise, in the cadastral municipality of Medana, there is only one land plot located in the plain which is defined as a field; every other is defined as a field with vines. A similar situation can be found in the Franciscean Cadastre. The classification of land plots that are situated in plains as fields with vines raises the question of its exact meaning. Were all levelled surfaces located in the plains of the previously mentioned cadastral municipalities entirely planted with vines? Furthermore, what was consequently the cultural landscape of the Gorica Hills like in the nineteenth century? Was it actually a cultural landscape, as it was registered and recorded in 1953 by the ethnologists of the Slovene Ethnographic $\mathrm{Mu}-$ seum? This is partly answered by the previously mentioned relevant studies that were carried out by geographers. They considered the Franciscean Cadastre's definitions of the cultivated land types and compared them to present-day images, thus establishing the changing percentage of the cultivated part of a landscape. I am referring to Franci Petek's study on the changes in land use in the northern Gorica Hills [65]. Petek classified the nineteenth-century fields - arativo - as fields and the fields with vines - arativo avidato - as vineyards [65]. The reason for such classification probably lies within the label arativo avidato. Did the expression field with vines actually refer to 
a vineyard situated in a plain area? The questions are also partly answered by the reports featured in the Franciscean Cadastre. To obtain the most accurate tax assessment possible, the appointed commissioners, together with the representatives of the communities, carefully catalogued the crop types, cultivation methods, the necessary material and labour. The Franciscan cadastre reports describe all the incomes and costs related to the cultivation of a land. The description includes what grew and how they cultivated the fields with vines and the so called brajdas, which are defined by the reports and cadastres with the Friulian term ronc [66].

The cadastre reports describe the plain areas of the Gorica Hills as very wet and swampy. The lack of arable land, like the system of the terraces on the hills, led to the construction of drainage canals between the individual land plots. The fields - arativo - were planted with crops on the surfaces between the canals based on the rotation that was in use. The fields with vines - arativo avidato on the contrary, had a different ratio between each cultivated culture. Singular lines of vines were planted on both sides of these canals, with some lines also on the fields. The vines were planted to the support of the trees in irregular groups, meaning on average (as was the usual number) five for each tree. One of the most common living supports was the willow tree, which also provided material for binding the vines and the necessary poles for support (Figure 5). There is also mention of the mulberry tree but to a much lesser extent. The canals were registered with an average width of $2 \frac{1}{2} \mathrm{ft}$ or $0.78 \mathrm{~m}$ [67]. On one joch or 0.57 ha [67] of field there were $334 \mathrm{~m}$ of canals and vines. Thus, one third of the surface on one joch was covered by vines and canals, whereas two third of the surface was used for cereal and legumes, i.e. for crops. The fields were planted with barley, turnip, corn, beans and broomcorn. All fields were also planted with fruit trees positioned in the lines between the vines, or where the lines concluded. On average, the fruit trees that grew on one joch were 1 mature and 3 young cherry trees, 14 peach trees, 2 plum trees and 5 fig trees [68].

Apart from the canals, the fields were crossed by trenches also during the trunk renewal of the vines. Most of the vines were renewed with cuttings. A trench that measured $2 \frac{1}{2} \mathrm{ft}$ in depth and $3 \mathrm{ft}$ in width was dug next to the exhausted line of vines. The cuttings were then planted in such trenches, and after 4 years, they were tied to a pole or a tree. While cleaning the canals (every 10 years), the exhausted soil around the vines was also replenished by digging it up and scattering it across the field. The fresh soil from the canals was scattered around the vines. This method was also useful for solving the problem of fertilisation. In fact, the orientation towards wine growing caused a shortage of surfaces for feeding cattle and, consequently, a shortage of suitable fertilisers.

Let us now focus on what a surface with planted crops looked like. Barley, turnips and broomcorn were planted by spreading the seeds manually. Corn was planted in a uniform distance. Beans were planted in groups and with the support of poles [68]. Therefore, the description of the fields enables a more detailed classification of the surfaces; at the same time, it also presents a difficult task. This kind of a field cannot be classified as a vineyard or a field, and especially not as an orchard. The fact remains that three different types of cultivated cultures coexisted on such fields, which, within our classification, can only be defined as a mixed culture. However, when we begin to study how the brajda was cultivated, even this kind of classification proves to be flawed.

How was the brajda that prevailed on the hills cultivated? Vines were planted in double lines, with single vines positioned $3 \mathrm{~m}$ from each other. The two lines of vines with shoots covered $3 \mathrm{~m}$ of terrace's surface. Thus, $1.6 \mathrm{~m}$ was available for growing cereal. The following trees were planted to support the vines: wild cherries, maple trees, field maple trees or elm trees. Here, the trees were planted next to the vines and not between two vines (Figure 6). That is why it was necessary to remove any shoots from the trees. The inner group of vines was attached to the tree, whereas the outer line was slightly leaning towards the slope. The lower shoots were supported by poles, whereas the upper ones were stretching up the tree. Brajdas were used for growing barley, beans (next to poles) and broomcorn. Crops were planted based on the rotation in use (Appendix 1). Fruit trees that grew between the vines did not have their excess branches pruned or cut off. The brajda on average featured on 1 joch: 3 mature and 6 semi-mature cherry trees, 2 mature and 3 young pear trees, 1 mature and 2 young apricot trees, 3 peach trees, 6 plum trees and 13 fig trees. A mature cherry, pear or apricot tree is considered to be one, whose trunk is equal to or larger than $1 \mathrm{ft}(31 \mathrm{~cm})$ in diameter. For a chestnut, the diameter is $1 \frac{1 / 2}{\mathrm{ft}}$ or more [68].

Terrace building was carried out manually and according to a specific process $[37,68]$. Brajdas cannot be classified as vineyards, even though the cadastre reports state that the vines are the prevailing cultivated crop. This cultivated plot could also be classified as a mixed culture; however, a problem then arises with regard to the field with vines. In fact, on both land plots the ratio between crops and vines was different, with a significant 


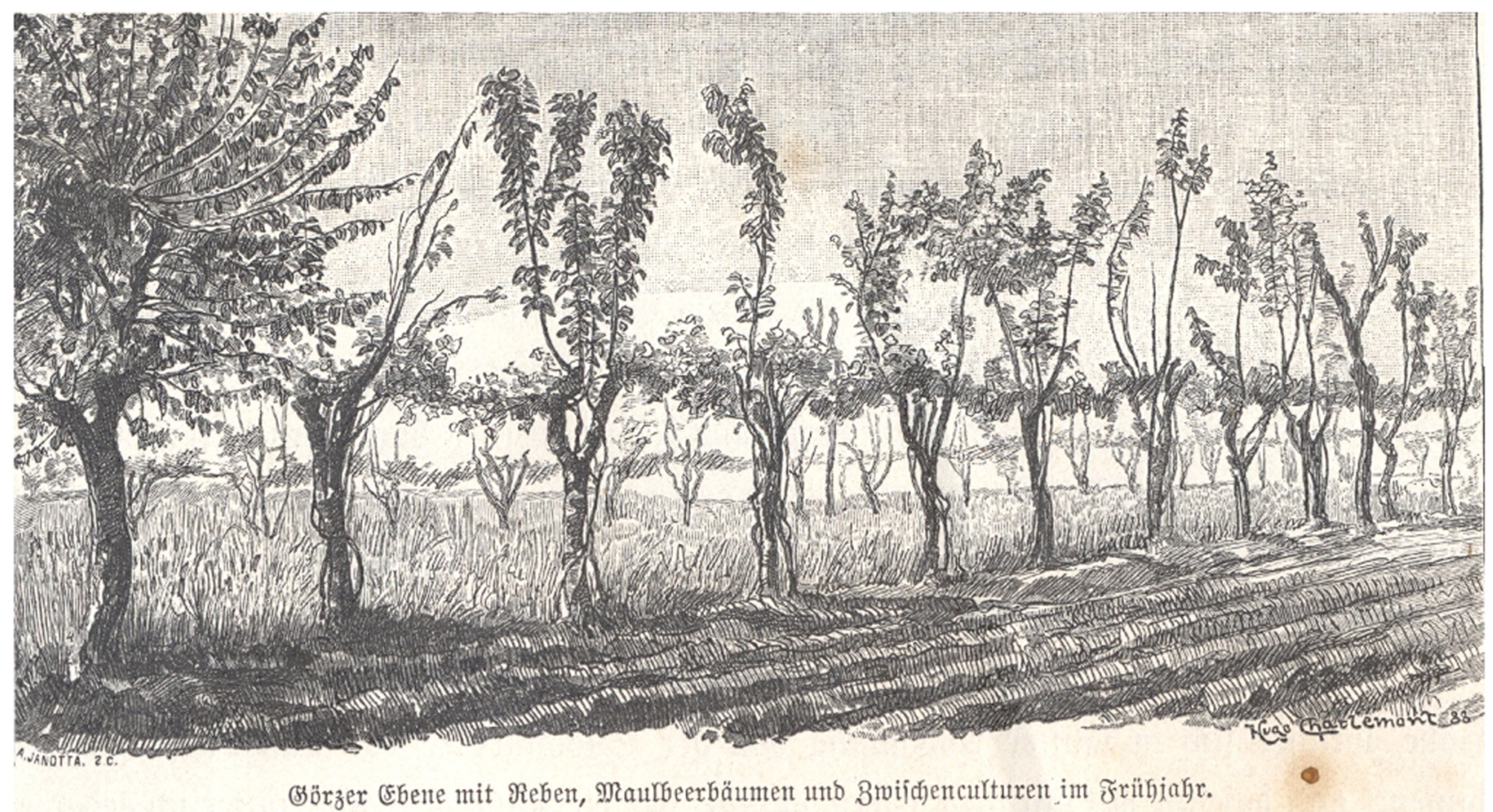

Figure 5: Field with vines, fruit trees and crops (source: Die österreichisch-ungarische Monarchie in Wort und Bild).

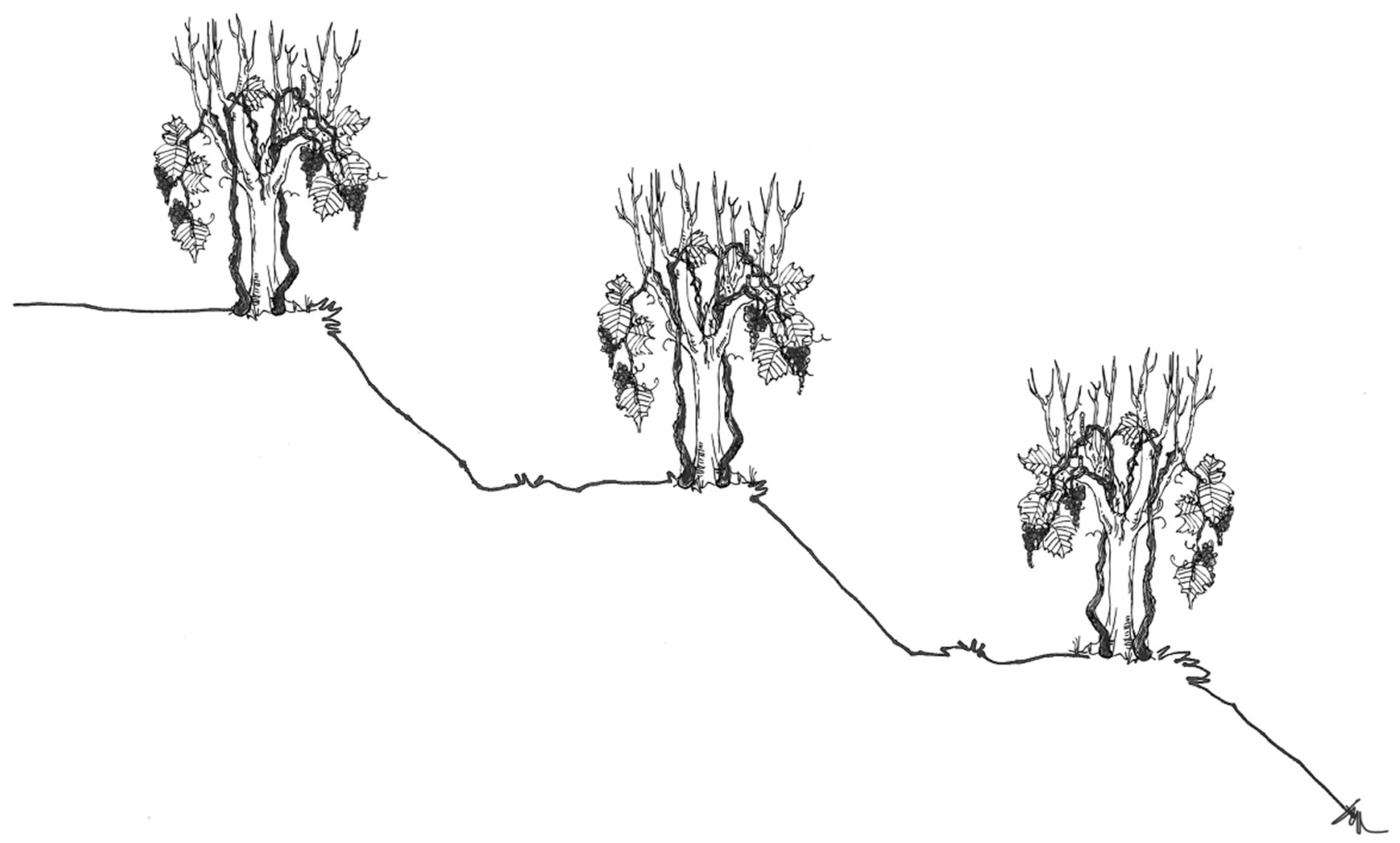

Figure 6: Reconstruction of the nineteenth-century system of terraces with the position of vines (author Nataša Gregorič MFA - Master Fine Arts). 
percentage of the two cultivated cultures on both land plots. We also cannot underestimate the percentage of fruit trees. I would therefore suggest the definitions as "field mixed cultivation" and "hill mixed cultivation."

\section{Discussion}

Based on what has been said, we can ascertain the importance of the cadastre reports as a source for the reconstruction of the cultural landscape. Based on the nineteenth-century descriptions, we can also clearly define what remains hidden and unanswered from the observer. The cultivated land plots are in part named differently from the post-WWII period, whereas the ones on the hills were called the same way: gardens and especially numerous brajdas; the plains were either named fields with vines or fields. Fields with vines as well as brajdas were cultivated land plots featuring varied plants that included vines, fruit trees and crops. These in modern times were converted into a vineyard, an orchard or a field. Nonetheless, it is necessary to point out that this is only true for the plains. In fact, nowadays the hills can feature a vineyard and an orchard. In some rare cases, crops can also be found. For this purpose, we suggest that the expressions be modified. These could be as suggested by us or by other expressions that should be adequate to the new situation.

\subsection{The advantages of reports data use}

The same denomination does not equal to the same method of growing fruit and especially growing vines. The crops being grown are partly the same and partly different (broomcorn). The cadastre reports also tell us that depending on the individual cadastral municipality different rotational crops existed, which were adapted to the circumstances. Even though the introduction of corn in the Gorica Hills happened early (seventieth century), it is still ongoing. According to the surveyors, the farmers of the cadastral municipality of Podsabotin planted corn also in brajdas, although unsuccessfully [69].

One may conclude that potato had not yet been grown in the Gorica Hills. However, the inventory registers record it as a supply that was kept in homes [70]. It was slowly being accepted and grown in small proportions in the gardens. We find out that the area was oriented towards wine growing, while fruit was slowly gaining importance, which is evident from the number of young trees. The farmers in the Gorica Hills were efficiently adapting to the new economic impulses, especially the growing number of the urban population, which increased the demand for fruit. Furthermore, this increased at the end of the nineteenth century after the construction of the railway line that connected the County of Gorizia with the Duchy of Carinthia, Lower Austria and Vienna [71]. We can thus follow since the end of the nineteenth century a marked increase in the plantation of fruit trees and, consequently, a growing number and introduction of specialised orchards.

The orientation towards wine growing meant a reduction in the surfaces for feeding cattle. Indoor livestock farming had not yet been introduced. The shortage of sufficient quantities of manure in the Gorica Hills and other parts of the Slovene territory [72] can thus be seen by the crop rotation with fallow land, as well as the planting of legumes and broomcorn. Researchers from the neighbouring Friuli plain have made similar observations [6]. As a comparison, we cite the crop rotation registered by the cadastre reports in the municipalities of Vipolže and San Floriano del Collio - Števerjan (INTEGRATION 1). In fact, all farmers were facing the challenge of maintaining the fertility of the soil, especially with a quantity of nitrogen that is sufficient for growing plants. In some neighbouring cadastral municipalities, farmers left out crop rotation but always kept one of the cultivated plots in fallow land [6]. Apart from leaving fallow land, when the bacteria in the soil converted the atmospheric nitrogen into the nitrogen in the soil, the legumes were also one of the plants that were able to convert atmospheric nitrogen into soil nitrogen. The plain areas in the brajdas, where legumes prevailed, represented a natural regulation system of nitrogen, which was also absorbed by vines. Modest mentioning of mulberry trees being used as living support in plains confirm that sericulture did not have a significant role in the Gorica Hills, as opposed to other areas of the County of Gorizia [71,73].

Before the manifestation of vine diseases: powdery mildew, downy mildew and phylloxera [74], the vine cultivation methods were different from what we know today and from what was known after WWI. Agrarian historians have become increasingly aware that phylloxera represents an important factor in the economic activity of the wine-growing regions [72]. The occurrence of these diseases required grafting of American rootstock, protective spraying and sprinkling [75], resulting in a reduced vine training system. Furthermore, the vines were no longer supported by trees (Figure 7) but were given smaller and larger supporting poles. Before the introduction of 


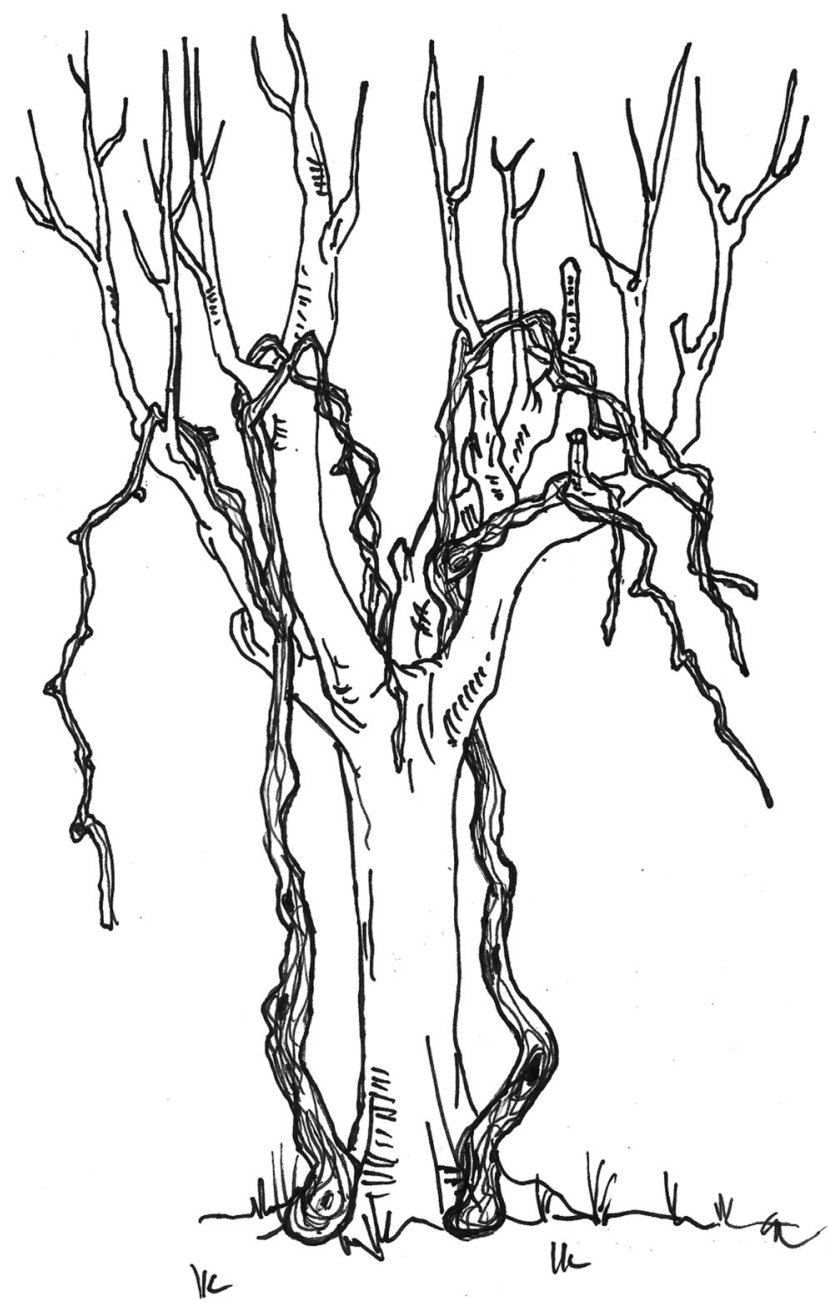

Figure 7: Reconstruction of vine training system in the Gorica Hills in the nineteenth century (author Nataša Gregorič MFA - Master Fine Arts).

machinery after WWII, the plain terrace surfaces were still being used for growing several crops [26]. Once machinery started being used, this space was no longer suitable for this purpose. Fruit trees also hindered the cultivation of vines with machines. As a result, monoculture was introduced, which we define as a vineyard, orchard or olive grove. Nevertheless, despite numerous modern machines, a large proportion of work (pruning, tying, harvesting and fruit picking) is still manual.

\subsection{The reports' flaws}

The cadastre reports do not give us any information on the depths of the canals, probably because they varied. It would also be interesting to know how they crossed one land plot. What is also missing is how high the vines stretched up the trees, how tall the fruit trees were and what the distance was between them and the vines. Furthermore, how high the vines grew, how many were actually tied to the living support and where exactly were the fruit trees planted between the vines. The descriptions of the sizes of the terraced surface, as well as the surface dedicated to cultivating vines and growing crops, certainly do not apply to the entire area, as then, even more so than today, farmers had to adjust to the inclination of the hill. We can assume that the descriptions apply as an average value to the described cadastral municipality; how high the terraced banks were and to what extent was it attempted to reduce the number of vines and other trees for the surveyors to create a lower yield for tax purposes. Which varieties of vines and fruit trees were being grown? Catalogues from the late nineteenth century cite numerous varieties, albeit linking them to a wider not a narrow area [76].

The existence and size of the so-called ecological niches, which are present in the Gorica Hills to this day, are graining importance, thanks to biodiversity [36]. They are borders that are overgrown by shrubs and trees as well as less accessible parts situated at the edges of land plots. We can learn about this fact from the war damage material, which describes a singular land plot as a combination of a cultivated field and a plot overgrown by shrubs and trees. An example from Kojsko: a vineyard planted in one piece with local vines and poles for bending the shoots, south-eastern direction with fruit trees 15 minutes of an hour from home near the main road, at the edge some oak trees and shrubs in good condition [78].

\section{Conclusion}

Despite a few imperfections, the Franciscean Cadastre reports represent a good source for studying and researching cultural landscape. By using and interpreting the available information and making comparisons with the situation after WWI [77], we can identify the changes in cultural landscape as well as the reasons for them. The cultural landscape of the Gorica Hills is the result of adaptations to economic and cultural impulses from inside and outside. During the research period, it is going through one of the development phases. Both cultivated land types, field with vines - arativo avidato - and brajda - ronco - feature a mixed cultivation of vines, fruit trees and crops in respectively different measures and with different training systems of the vine. Therefore, researchers define cultural landscape as an intensive form of agriculture, as it strives 
to fully exploit the cultivated plots [4]. It is cited by researchers from Slavia Friulana [78], the Karst (Panjek) and the wider outskirts of Gorizia [73,79]. Cultivated terraces are a prominent feature of the Mediterranean agricultural landscape [80]. Bibliography connected with the research on land use changes is already represented in detail in the article "Land-use changes in Slovenian terraced landscapes” [55].

Petek explained that the Gorica Hills have a distinctly dual appearance. In their southern part, agricultural land surface has remained almost the same since the first half of the nineteenth century. In contrast, the northern part of Gorica Hills has experienced intensive overgrowth. The proportion of forest today is more than $80 \%$, whereas during the period of the greatest extent of farmland it only covered $30 \%$ [65]. The results can be compared with the research of the Italian regions. In Lamole, there is a $40 \%$ reduction in the conservation of the terraces, but nevertheless the specialised vineyards have progressively expanded since 1954. The situation in the southern Gorica Hills area is more like the situation in Valdobbiadene, where the principal characteristics of the traditional landscape have remained almost intact over the last 50 years, even if there have been changes to land use and the structure of the landscape mosaic [81]. Reduction is also notable in the case of steep slopes, remote areas and uninhabited islets in the Adriatic Croatia region [82]. Therefore, we can argue that labour-intensive terrace construction and maintenance are possible under specific socioeconomic conditions. In the cases of big labour input and very low incomes, the terraces were abandoned as stressed on The Serra de Rodes catchment [83] or Lesvos [84] cases.

Nowadays, the Gorica Hills are a terraced landscape with the predominant culture of vines but also with fruit trees, among which recently also olives grow. Consequently, the nineteenth century can be considered as the period of the definite introduction of corn and potatoes. The area of the Gorica Hills is primarily oriented towards wine growing and to a lesser extent also fruits. Other crops serve only to support the existence of the farmer's family. Because of the occurrence of new vine diseases, the late nineteenth century represents the search to find new solutions for cultivating the vine and increasing the cultural terraces in the light of a favourable economic situation. However, we cannot compare our study with studies that dealt with changes to agricultural land based on categories in the Franciscean Cadastre, as the land category itself defined in the Franciscean Cadastre is not always consistent with today's categories. However, the results are important to what extent the once cultivated land has been overgrown or to what extent the uncultivated land has changed to the cultivated one and why is this so. To get the most accurate results, the best possibility is developing interdisciplinary research combining various historical materials with modern possibilities of analysing geographical space changes (GIS).

\section{References}

[1] European Landscape Convention; 2000. https://www.coe.int/ en/web/conventions/full-list/-/conventions/treaty/176.

[2] Urbanc M, Kulturne pokrajine v Sloveniji (Cultural landscapes in Slovenia). Ljubljana: Založba ZRC; 2002.

[3] Cultural Landscapes: The Challenges of Conservation. World Heritage 11-12 November 2002. https://unesdoc.unesco.org/ ark:/48223/pf0000132988.

[4] Panjek A. Človek, zemlja, kamen in burja: zgodovina kulturne krajine Krasa (oris od 16. do 20. stoletja). Koper: Univerza na Primorskem, Znanstveno-raziskovalno središče, Založba Annales, Zgodovinsko društvo za južno Primorsko; 2006.

[5] Panjek A. Kulturna krajina in okolje Krasa: o rabi naravnih virov v novem veku. Koper: Založba Univerze na Primorskem; 2015.

[6] Bianco F. Nobili castellani, comunità, sottani: il Friuli dalla caduta della repubblica alla restaurazione. Monfalcone; Edizioni della Laguna; 1997.

[7] Bianco F. Monfalcone e il territorio: alle origini dell'industrializzazione: dall'economia rurale allo sviluppo manifatturiero. Monfalcone: Edizioni della Laguna; 1988.

[8] Bianco F. Le terre del Friuli: la formazione dei paesaggi agrari in Friuli tra il XV e il XIX secolo. Mantova, Cierre edizioni, Verona: Astrea; 1994.

[9] Naravni viri v Alpah: socialna in okoljska vzdržnost srenjskih, individualnih in javnih oblik upravljanja: povzetki = Natural assets in the Alps: social and environmental sustainability of community, individual and public forms of management. International Association for Alpine History. Koper; Znanstvenoraziskovalni center Slovenske akademije znanosti in umetnosti, Ljubljana, Univerza na Primorskem; Znanstvenoraziskovalno središče; 2013.

[10] Andlar G, Šrajer F, Trojanović A. Discovering cultural landscape in Croatia: History and classification of Croatian Adriatic enclosed landscape. Annals for Istrian and Mediterranean studies. Ser historia et sociologia. 2018;28(4): 759-78, https://www.dlib.si/details/URN:NBN:SI:docF3610D1W.

[11] Miller PJ, Fossey R. editor. Mapping the Catholic cultural landscape. Lanham: Rowman \& Littlefield; 2004.

[12] Dohnal M. Historická kulturní krajina v novověku: vývoj vsi a plužiny v Borovanech u Bechyně. Praha: Ústav archeologické památkové péče středních Čech; 2003.

[13] The changes of the cultural landscape: ICMAH in Denmark, October 7th till 12th 1990, Prehistoric Museum Moesgård, Århus [and] Svendborg County Museum. Prehistoric Museum Moesgård; Århus: Svendborg County Museum; 1991.

[14] Smout TC, editor. Understanding the historical landscape in its environmental setting. Dalkeith: Scottish Cultural Press; 2002. 
[15] Hernik J. Cultural landscape: across disciplines. Bydgoszcz, Kraków; Oficyna wydawnicza Branta; 2009.

[16] Rubenstein JM. The cultural landscape: an introduction to human geography. Harlow: Pearson Education, Cop.; 2018.

[17] Birks HH, Birks HJB, Kaland PE, Moe D, editors. The cultural landscape: past, present, and future. Cambridge University Press, Cambridge; 1999.

[18] Wallach B. Understanding the cultural landscape. New York: Guilford Press, Cop.; 2005.

[19] Hernik J, Pijanowski JM. Cultural landscape: assessment, protection, shaping. Kraków: Wydawnictwo AR; 2007.

[20] Bollig M, Bubenzer O. African landscapes: interdisciplinary approaches. New York [London]: Springer; 2009.

[21] Martini IP, Chesworth W, editors. Landscapes and societies: selected cases. Dordrecht, New York: Springer; 2010.

[22] Jordan-Bychkov TG. The Human Mosaic. A Thematic Introduction to Cultural Geography, 8th ed. New York; 1999.

[23] Forejt M, Dolejš M, Zacharová J, Raška P. Quantifying inconsistencies in old cadastral maps and their impact on land-use reconstructions. J Land Use Sci. 2020. 1-15. doi: 10.1080/ $1747423 X .2020 .1765427$.

[24] Marušič B. Brda in državne meje (1797-1947). In: Stres $P$, editor. Občina Brda. Briški zbornik. Dobrovo: Občina Brda; 1999. p. 116-31.

[25] Kladnik D. Goriška Brda. In: Belec B, Fridl J, Gabrovec M, Hrvatin M, Kert B, Kladnik D. et al., editors. Slovenija: pokrajina in ljudje. Ljubljana: Mladinska knjiga; 1998. p. 210-9.

[26] Momirski Ažman L, Kladnik D, Komac B, Petek F, Repolusk P, Zorn M. Terasirana pokrajina Goriških brd (Terraced landscape in Goriška brda). Ljubljana: Založba ZRC; 2008.

[27] Pavlin V. Goriško gospostvo ob prehodu pod Habsburžane na osnovi urbarja iz leta 1507 (La signoria fondiaria di Gorizia nel passaggio agli Asburgo sulla base dell'urbario dell'anno 1507). Nova Gorica: Goriški muzej Grad Kromberk; 2006.

[28] Osmuk N. Gonjače. Varst spomenikov. 1993;34:216.

[29] Bidasio A. I vini del Friuli-Venezia Giulia. In: Perusini Antonini G, editor. Mangiare e ber friulano. Milano: Angeli; 1977. p. 257-79.

[30] Bolle I. I terreni del Goriziano in rapporto alla loro adattabilità per la coltura delle viti americane. Gorizia: Paternolli; 1896.

[31] Vidrih-Perko V, Žbona Trkman B. Trgovina in gospodarstvo v Vipavski dolini in Goriških Brdih v rimski dobi (Trade and economy in the valley of Vipava river in the roman time). Goriški letnik. 2003-2004;31-32:17-72.

[32] Kos F. Goriška brda v srednjem veku. In: Stres P, editor. Briški zbornik. Dobrovo: Občina Brda; 1999. p. 32-73.

[33] Archivio di stato Trieste, Archivio della Torre e Tasso, busta 180.1.2.1.

[34] Archivio di stato Gorizia, Catasto teresiano, Quisca, reg. 30.

[35] Archivio di stato Gorizia, Catasti sec. XIX-XX, Elaborati, Operato d'estimo della comune di San Floriano del Collio, reg. 66.

[36] Vrišer I. Goriška brda: Gospodarska geografija (Goriška brda in Slovenia: The Economic Geography). Geografski zbornik. 1954;2:51-113.

[37] Stres P. Oris preteklosti vinogradništva v Goriških brdih do druge svetovne vojne. In: Stres P, editor, Briški zbornik. Dobrovo: Občina Brda; 1999. p. 303-32.
[38] Ribnikar P. Zemljiški kataster kot vir za zgodovino (Das Grundsteuerkataster als Geschichtsquelle). Zgodovinski časopis. 1982;36:321-37. http://hdl.handle.net/11686/13504.

[39] Demšar B. Geodetske evidence v Sloveniji - zemljiški kataster. In: Zgodovina slovenske geodezije in geofizike: zbornik predavanj. Ljubljana: Ministrstvo za okolje in prostor, Uprava Republike Slovenije za geofiziko; 1995. p. 15-30.

[40] Petek F, Urbanc M. The Franziscean Land Cadastre as a key to understanding the 19th-century cultural landscape in Slovenia = Franciscejski kataster kot ključ za razumevanje kulturne pokrajine v Sloveniji v 19. stoletju. Acta geographica Slovenica. 2004;44(1):89-113. doi: 10.3986/AGS44104.

[41] Golec B. Zemljiški katastri 18. in 19. stoletja kot vir za stavbno, gradbeno in urbanistično zgodovino slovenskega ozemlja - 2 . del (land cadastres of the 18th and 19th centuries as sources for the building and urbanistic history of the Slovenian territory - part 2). Arhivi. 2010;33(2):339-96, https://www.dlib.si/ details/URN:NBN:SI:doc-5UZUAEKS.

[42] Verbič M. Škofja Loka v luči cenitve katastrskega dohodka leta 1827 in 1830. Kronika. 1969;17(3):161-7.

[43] Blaznik P. Bitenj in franciscejski kataster (Die Gemeinde Bitenj und der franziszeische Kataster). Loški razgledi. 1975;22(1):83-93.

[44] Granda S. Zgornja Baška dolina v prvi polovici 19. stoletja. Kronika. 1994;42(1):52-8.

[45] Trpin D. Tolmin z okolico ob koncu 18. in začetku 19. stoletja: po podatkih iz katastra. In: Tolminski zbornik 3. Tolmin: Občina Tolmin; 1997. p. 159-65.

[46] Drobesch W. Bodenerfassung und Bodenbewertung als Teil einer Staatsmodernisierung: Theresianische Steuerrektifikation, Josephinischer Kataster und Franziszeischer Kataster. In: Furter A, Head-König L, editors, Les migrations de retour. Zürich: Ruckwanderungen; 2009. p. 165-85.

[47] Seručnik M. Countryside on the brink of modernity: Josephinian and Franciscan cadastres as sources for the ecohistory of Carniola. In: Štih P, Zwitter Ž, Simoniti V, Krahwinkler $\mathrm{H}$, editors. Man, nature and environment between the northern Adriatic and the eastern Alps in pre-modern times. Ljubljana: Znanstvena založba Filozofske fakultete $=$ University Press, Faculty of Arts, Historical Association of Slovenia; 2014. p. 182-91.

[48] Kačičnik-Gabrič A. Kmečko življenje v Zgornje savski dolini v 18. in 19. stoletju (Rural life in the upper Sava valley in the 18th and 19th centuries). Kronika. 2016;64(3):495-512, https:// kronika.zzds.si/kronika/article/view/571/805.

[49] Rajšp V. "Landesaufnahmen" und Katastralvermessungen vom "Censimento Milanese" bis zur Franzisko-Josephinischen Grundbuchsordnung. In: Drobesch W. (Ed), Kärnten am Übergang von der Agrar- zur Industriegesellschaft: Fallstudien zur Lage und Leistung der Landwirtschaft auf der Datengrundlage des Franziszeischen Katasters (1823-1844). Klagenfurt am Wörthersee: Verlag des Geschichtsvereines für Kärnten; 2016. p. 43-7.

[50] Moritsch A. Das nahe triester Hinterland: zur wirtschaftlichen und sozialen Entwicklung vom Beginn des 19. Jahrhunderts bis zur Gegen wart. Graz: H. Böhlaus Nachf.; 1969.

[51] Rumpler H, Scharr K, Ungureanu C, Liebhart WT, Kollegger M, Bäck R. Der Franziszeische Kataster im Kronland Bukowina Czernowitzer Kreis (1817-1865): Statistik und Katastralmappen. Weimar, Wien, Köln: Böhlau Verlag; 2015. 
[52] Bičík I, Gabrovec M, Kupková L. Long-term land-use changes: A comparison between Czechia and Slovenia. Acta geographica Slovenica. 2019;59(2):91-105. doi: 10.3986/AGS.7005.

[53] Kupková L, Bičík I, Boudný Z. Long-term land-use/land-cover changes in Czech border region. Acta geographica Slovenica. 2019;59(2):107-17. doi: 10.3986/AGS.7191.

[54] Gabrovec M, Bičik I, Komac B. Franciscean land cadaster as a source of studying landscape changes. Acta geographica slovenica. 2019;59(2):89-113. doi: 10.3986/AGS.7349.

[55] Kladnik D, Geršič M, Pipan P, Volk Bahun M. Land-use changes in Slovenian terraced landscapes. Acta geographica Slovenica. 2019;59(2):119-41. doi: 10.3986/AGS.6988.

[56] Ribeiro D, Šmid Hribar M. Assessment of land-use changes and their impacts on ecosystem services in two Slovenian rural landscapes. Acta geographica Slovenica. 2019;59(2):143-59. doi: 10.3986/AGS.6636.

[57] Foški M, Zavodnik Lamovšek A. Monitoring land-use change using selected indices. Acta geographica Slovenica. 2019;59(2):161-75. doi: 10.3986/AGS.5276.

[58] Gabrovec M, Kumer P. Land-use changes in Slovenia from the Franciscean Cadaster until today. Acta geographica Slovenica. 2019;59(2):63-82. doi: 10.3986/AGS.4892.

[59] Geršič M, Gabrovec M, Zwitter Ž. Primerjava kulturne pokrajine Hraških listnekov in tamkajšnjega kmetovanja v prvi polovici 19. stoletja in danes (Comparing the cultural landscape of Hraški Listneki and farming there in the first half of the nineteenth century and today). Geografski Vestn. 2018;90(1):61-84. doi: 10.3986/GV90104.

[60] Yang Y, Zhang S, Yang J, Chang L, Bu K, Xing X. A review of historical reconstruction methods of land use/land cover. J Geographical Sci. 2014;24:746-66. doi: 10.1007/s11442014-1117-z.

[61] Bičík I, Jeleček L, Štěpánek V. Land-use changes and their social driving forces in Czechia in the 19th and 20th centuries. Land Use Policy. 2001;18:65-73. doi: 10.1016/S02648377(00)00047-8.

[62] Bičík I, Kupková L, Jeleček L, Kabrda J, Štych P, Janoušek Z, et al. Land use changes in the Czech Republic 1845-2010. Cham, Heidelberg, New York, Dordrecht, London: Springer; 2015.

[63] Slovenski etnografski muzej, teren 10, 1953, Terenski zvezki: Boris Orel Gospodarstvo, Jernej Šušteršič Vinogradništvo, sadjarstvo.

[64] Zuljan Kumar D. Odraz slovensko-furlanskega jezikovnega stika $v$ leksiki pomenskih polj polje, vrt in sadovnjak v govoru Medane (Reflection of Slovenian-Friulian language contact in the lexis of the semantic fields "field, garden and orchard" in the Medana local dialect). In: Jesenšek M., editor. Izzivi sodobnega slovenskega slovaropisja. Maribor: Mednarodna založba Oddelka za slovanske jezike in književnosti; 2011. p. 287-304.

[65] Petek F. Spreminjanje rabe tal v severnih Goriških brdih (Land use changing in northern Goriška brda). Geografski Vestn. 2007;79(1):9-23, https://www.dlib.si/details/ URN:NBN:SI:DOC-F5X5ONHP.

[66] Valenčič V. Vrste zemljišč. In: Blaznik P, Grafenauer B, Vilfan S, Zwitter F. Gospodarska in družbena zgodovina Slovencev, Zgodovina agrarnih panog. Zv. 1, Agrarno gospodarstvo. Ljubljana: SAZU, DZS; 1970. p. 131-46.

[67] Bajt D. Vsevednik. Ljubljana: Tehniška založba Slovenije; 1999.
[68] Archivio di stato Gorizia, Catasti sec. XIX-XX, Elaborati, Operato d'estimo della comune di Cerou superiore ed inferiore, busta 15 .

[69] Archivio di stato Gorizia, Catasti sec. XIX-XX, Elaborati, Operato d'estimo della Comune di San Mauro e Podsenizza (con Podsabotino), busta 69.

[70] Gomiršek T. Spremembe na področju agrarnih panog v jugovzhodnem delu Goriških brd v 19. stoletju (Agrarian changes in the southeastern part of the Goriška brda in the 19th century). Kronika. 2011;59(2):257-82, https://www.dlib.si/ details/URN:NBN:SI:doc-MY4NKHS4.

[71] Czoernig C. Gorizia la Nizza austriaca. Il territorio di Gorizia e Gradisca I. Gorizia: Cassa di risparmio di Gorizia; 1987.

[72] Seručnik $M$. Trtna uš, ta strašno drobna pošast. Ljubljana: Zgodovinski inštitut Milka Kosa ZRC SAZU; 2011.

[73] Bianco F. L'armonia sociale nelle campagne: Economia agricola e questione collonica nella principesca Contea di Goriza e Gradisca tra ' 800 e ' 900 . In: Bianco F, Massau Dan M, editors. Economia e società nel Goriziano tra 800 e 900 : il ruolo della Camera di Commercio (1850-1915). Gorizia: Edizioni della Laguna; 1991. p. 33-66.

[74] Gomiršek T. Rebula nekoč in danes. Nova Gorica: Goriški muzej; 2007.

[75] Valenčič V. Vinogradništvo. In: Blaznik P, Grafenauer B, Vilfan S, Zwitter F, Gospodarska in družbena zgodovina Slovencev, Zgodovina agrarnih panog. Zv. 1, Agrarno gospodarstvo. Ljubljana: SAZU, DZS; 1970. p. 279-308.

[76] Costantini E, Mattaloni C, Petrussi C. La vite nella storia e nella cultura del Friuli. Udine: Forum; 2007.

[77] Archivio di stato Gorizia, Giudizio distrettuale di Gorizia 1898-1922, Danni di guerra del circondario di Gorizia, busta 860, akt 2562.

[78] Beguš I. Avtonomija in ekonomija Nadiških dolin v Beneški republiki (Autonomia ed economia delle Valli del Natisone nella Repubblica di Venezia). Koper: Univerzitetna založba Annales; 2015.

[79] Rutar S. Poknežena grofija Goriška in Gradiščanska. Ljubljana: Branko, Nova Gorica, Jutro; 1997.

[80] Kladnik D. Terraced landscapes: commemorating seventy years of the Anton Melik Geographical Institute ZRC SAZU, Ljubljana: Založba ZRC; 2017.

[81] Agnoletti M, Cargnello G, Gardin L, Santoro A, Bazzoffì P, Sansone L, et al. Traditional landscape and rural development: Comparative study in three terraced areas in northern, central and southern Italy to evaluate the efficacy of GAEC standard 4.4 of cross compliance. Italian J Agron. 2011;6(1):121-39. doi: 10.4081/ija.2011.6.s1.e16.

[82] Andlar G, Šrajer F, Trojanović A. Classifying the Mediterranean terraced landscape: The case of Adriatic Croatia. Acta geographica Slovenica. 2017;57(2):111-29. doi: 10.3986/ AGS.4673.

[83] Dunjò G, Pardini G, Gispert. M. Land use change effects on abandoned terraced soils in a Mediterranean catchment, NE Spain. Catena. 2003;52(1):23-37. doi: 10.1016/S03418162(02)00148-0.

[84] Kosmas C, Gerontidis S, Marathianou M. The effect of land use change on soils and vegetation over various lithological formations on Lesvos (Greece). Catena. 2000;40(1):51-68. doi: 10.1016/S0341-8162(99)00064-8. 


\section{Appendix}

\section{INTEGRATION 1}

Vipolže crop rotation on a field with vines, classes 1-3:

- 1st year: barley (manure), then turnip on manure

- 2nd year: corn, then beans

- 3rd to 6th year: corn, then beans

Vipolže crop rotation on brajda, classes 1 and 2:

- 1st year: beans (dug, ploughed and fertilised)

- 2nd year: barley (dug, ploughed and fertilised)

- 3rd to 15th year: broomcorn and beans

Vipolže crop rotation on brajda, class 3:

- 1st year: beans (dug, ploughed and fertilised)

- 2nd year: barley (dug, ploughed and fertilised)

- 3rd to 6th year: broomcorn and beans

- 7th to 15th year: beans

Vipolže crop rotation on brajda, class 4:

- 1st year: beans (dug, ploughed and fertilised)

- 2nd year: barley (dug, ploughed and fertilised)

- 3rd to 6th year: broomcorn and beans

- 7th to 10th year: beans

- 11th to 15th year: fallow land
Števerjan crop rotation on a field with vines, class 1:

- 1st year: barley (manure), then turnip on manure

- 2nd to 4th year: corn, then beans

Števerjan crop rotation on a field with vines, class 2:

- 1st year: barley (manure), then turnip on manure

- 2nd and 3rd year: corn, then beans

- 4th year: broomcorn, then beans

Števerjan crop rotation on brajda, classes 1 and 2:

- 1st year: beans (dug, ploughed and fertilised)

- 2nd year: barley (dug, ploughed and fertilised)

- 3rd to 9th year: broomcorn and beans

Števerjan crop rotation on brajda, classes 3 and 4:

- 1st year: beans (dug, ploughed and fertilised)

- 2nd year: barley (dug, ploughed and fertilised)

- 3rd and 4th year: broomcorn and beans

- 5th to 10th year: beans 